\title{
ANALISIS AWAL PENERAPAN KLASTER INDUSTRI PERKAPALAN DI BATAM
}

\author{
Vera Methalina Afma \\ Dosen Tetap Prodi Teknik Industri Universitas Riau Kepulauan
}

\begin{abstract}
ABSTRAK
Batam merupakan salah satu daerah yang ikut memicu perkembangan perekonomian di Indonesia. Hal ini disebabkan karena letak geografis Batam yang strategis, yang berlokasi di daerah segitiga (SI-JO-RI) dengan pertumbuhan ekonomi tercepat di Asia Tenggara. Di tahun 1970an ketika Batam masih berada pada tahap perkembangan, Singapura memainkan peranan penting yang membantu Batam mengembangkan basis industrinya. Dengan adanya perubahan hubungan ekonomi antara Batam dengan Singapura, maka sangat penting bagi Batam untuk melalui pergeseran paradigma agar dapat tetap kompetitif di kawasan dan global. Salah satu caranya adalah dengan melakukan klaster industri pada industri perkapalan.

Adapun tujuan dari penelitian ini adalah mendeskripsikan gambaran rantai nilai industri perkapalan di Batam dan mengidentifikasi penerapan klaster industri perkapalan yang ada di Batam.

Hasil penelitian menyimpulkan gambaran rantai nilai industri perkapalan di Batam adalah Rantai nilai yang berlaku di industri perkapalan di Batam bermula dari proses $R \& D$ yang saat ini masih dilakukan oleh industri pemesan, dilanjutkan dengan kegiatan produksi pembuatan kapal dengan melibatkan industri pemasok yang ada di daerah Batam dan di sekitarnya serta dari luar negeri, seperti Singapura. Industri perkapalan di Batam, material yang digunakan sebesar $70 \%$ masih dipasok dari negera luar. Industri pemasok meliputi industri yang memproduksi Shipboard systems, Electrical systems, Automation systems, Paints \& Insulation, Furniture \& Deco, Navigation equipment, Mechanical equipment, Steel \& other materials dan yard maintenance. Selanjutnya dilakukan proses assembly dan penjualan kepada pemesan atau konsumen lainnya, yang diikuti juga dengan kegiatan service after sales, artinya memberikan layanan purna jual terhadap kapal yang sudah dibuat. Misalnya memberikan jaminan repair, maintenance dan konversi.
\end{abstract}

Kata kunci : klaster industri, industri kapal, Shipboard systems, Electrical systems, Automation systems, Paints \& Insulation, Furniture \& Deco, Navigation equipment, Mechanical equipment, Steel \& other materials dan yard maintenance

\section{PENDAHULUAN}

Batam merupakan salah satu daerah yang ikut memicu perkembangan perekonomian di Indonesia. Hal ini disebabkan karena letak geografis Batam yang strategis, yang berlokasi di daerah segitiga (SI-JO-RI) dengan pertumbuhan ekonomi tercepat di Asia Tenggara.

Di tahun 1970an ketika Batam masih berada pada tahap perkembangan, Singapura memainkan peranan penting yang membantu Batam mengembangkan basis industrinya. Hal ini dilakukan melalui pemfasilitasan kegiatan perusahaan manufaktur asing dalam merelokasi ke Batam. Selama masa tersebut Batam secara ekonomi telah berkembang pesat. Pertumbuhan ekonomi yang pesat tersebut telah menarik tenaga kerja dari seluruh Indonesia. Status Kawasan Berikat yang teLah diberikan kepada Batam telah membantu kawasan berkembang lebih jauh lagi. 
Oleh karena itu, dengan adanya perubahan hubungan ekonomi antara Batam dengan Singapura, maka sangat penting bagi Batam untuk melalui pergeseran paradigma agar dapat tetap kompetitif di kawasan dan global. Salah satu caranya adalah dengan melakukan klaster industri, dengan mengembangkan delapan industri utama yang ada di Batam. Dalam pekerjaan ini, hanya fokus pada industri perkapalan.

\section{TEORI KLASTER INDUSTRI}

Istilah "klaster (cluster)" mempunyai pengertian harfiah sebagai kumpulan, kelompok, himpunan, atau gabungan obyek tertentu yang memiliki keserupaan atau atas dasar karakteristik tertentu. Dalam konteks ekonomi/bisnis, "klaster industri (industrial cluster)" merupakan terminologi yang mempunyai pengertian khusus tertentu.

Adapun manfaat dari klaster industri menurut Porter, 1998a; Desrochers dan Sautet, 2004; Waits, 2000 adalah :

1. Menciptakan manfaat ekonomi dan daya saing,

2. Meningkatkan efisiensi dan produktivitas bagi perusahaan di dalam klaster serta peningkatan kemampuan inovasi yang melibatkan lembaga penelitian,

3. Mengurangi biaya transportasi dan transaksi, meningkatkan efisiensi

4. Menciptakan aset secara kolektif dan memungkinkan terciptanya inovasi yang pada akhirnya akan meningkatkan produktifitas

5. Memiliki keunggulan dalam memanfaatkan aset sumberdaya secara kolektif untuk mendorong diversifikasi produk dan meningkatkan terciptanya inovasi

6. Mendorong terjadinya spesialisasi produksi sesuai dengan kompetensi inti

7. Mendorong transformasi keunggulan komparatif menjadi keunggulan kompetitif

Para pelaku (stakeholders) dalam klaster industri dapat dibagi ke dalam enam kelompok, yaitu :

1. Industri Inti, yaitu industri yang merupakan fokus perhatian dan menjadi pengamatan kita dalam klaster, biasanya dijadikan titik maksud kajian.

2. Industri Pemasok, yaitu industri yang memasok bahan baku, bahan pembantu atau kelengkapan lainnya, dengan kata lain industri yang menghasilkan produk-produk yang digunakan dalam proses produk industri ini yang dipasok antara lain : bahan baku utama, bahan tambahan dan aksesori

3. Industri Pendukung, yaitu industri yang mendukung suatu produk yang dihasilkan, dengan kata lain industri yang meneyediakan jasa-jasa pendukung yanga diperlukan untuk pelaksanaan program inti. Industri pendukung ini antara lain terdiri dari :

a. Pembiayaan (bank, modal ventura)

b. Jasa (angkutan bisnis, distribusi, konsultan bisnis)

c. Infrastruktur (Jalan raya, telekomunikasi, listrik)

d. Peralatan (Permesinan, alat bantu)

e. Pengemasan

f. Penyedia jasa pengembangan bisnis

4. Pengguna, yaitu Industri yang memakai atau menggunakan produk yang dihasilkan industri inti. Pengguna atau pembeli dapat berupa :
a. Pemakai langsung (owner atau operator)
b. Distributor
c. Pengecer

5. Institusi Pendukung, yaitu institusi non industri yang dapat berupa :

a. Lembaga pemerintah yang berupa penentu kebijakan atau melaksanakan peran publik

b. Asosiasi profesi yang bekerja untuk kepentingan anggota

c. Lembaga pengembang swadaya masyarakat yang bekerja pada bidang khusus yang mendukung 
Kelima stakeholder yang telah dijelaskan di atas, dapat dilihat dari gambar berikut ini.

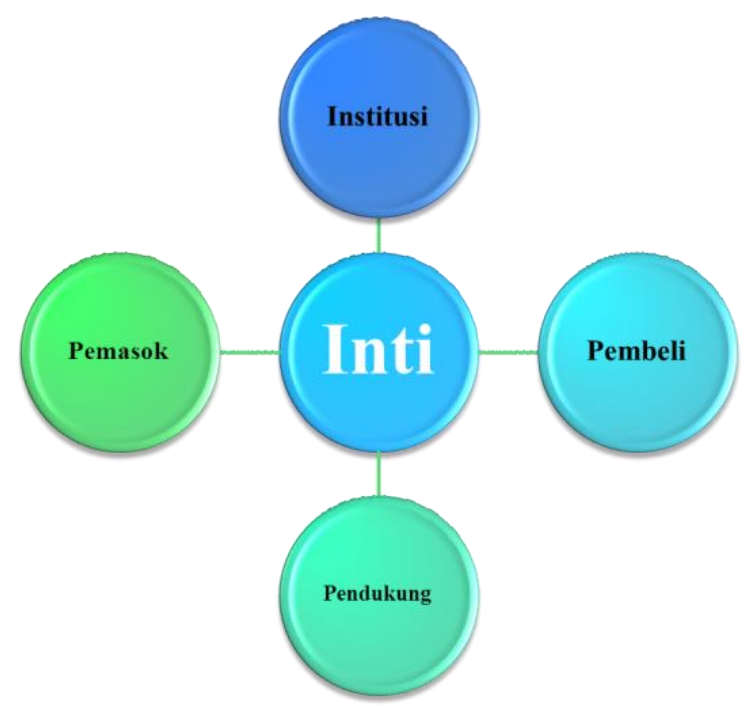

Gambar 1.

Stakeholder Klaster Industri

\section{HASIL PENELITIAN}

Batam terdiri dari berbagai jenis industri. Jenis industri tersebut dapat dilihat dari Tabel 1. Dari tabel dapat dilihat bahwa industri perkapalan berkontribusi paling besar dalam perkembangan industri di kota Batam yaitu sebesar 30\% dengan adanya 46 industri dari tahun $2001-2012$.

Tabel 1. Persentase dan Jenis Industri di Batam Tahun 2001-2012 


\begin{tabular}{|l|r|r|}
\hline \multicolumn{1}{|c|}{ Jenis Industri } & Jumlah & Persentase \\
\hline Industri Perkapalan & 46 & $30 \%$ \\
\hline Industri Kemasan dalam Plastik & 14 & $9 \%$ \\
\hline Industri Barang dari Kayu/Gabus & 13 & $8 \%$ \\
\hline Industri roti dan sejenisnya & 6 & $4 \%$ \\
\hline Industri air minum dalam kemasan & 6 & $4 \%$ \\
\hline Industri Pakaian Jadi dan perlengkapannya & 21 & $14 \%$ \\
\hline Indsutri molding dan komponen bahan bangunan & 6 & $4 \%$ \\
\hline Industri Kemasan dan Kotak dari Karton & 10 & $7 \%$ \\
\hline Industri Percetakan & 18 & $12 \%$ \\
\hline Reproduksi Film/Video & 1 & $1 \%$ \\
\hline Industri Barang-Barang Peralatan Elektronik & 12 & $8 \%$ \\
\hline Total & 153 & $\mathbf{1 0 0 \%}$ \\
\hline
\end{tabular}

Sumber : Disperindag EDM Kota Batam Bidang Industri

Keempat puluh enam industri tersebar di beberapa wilayah di Pulau Batam yang mendekati wilayah laut, diantaranya Batu Ampar, Sekupang, Tanjung Uncang, Kabil dan beberapa daerah lainnya. Peta persebaran industri perkapalan ini dapat dilihat dari Gambar 2.

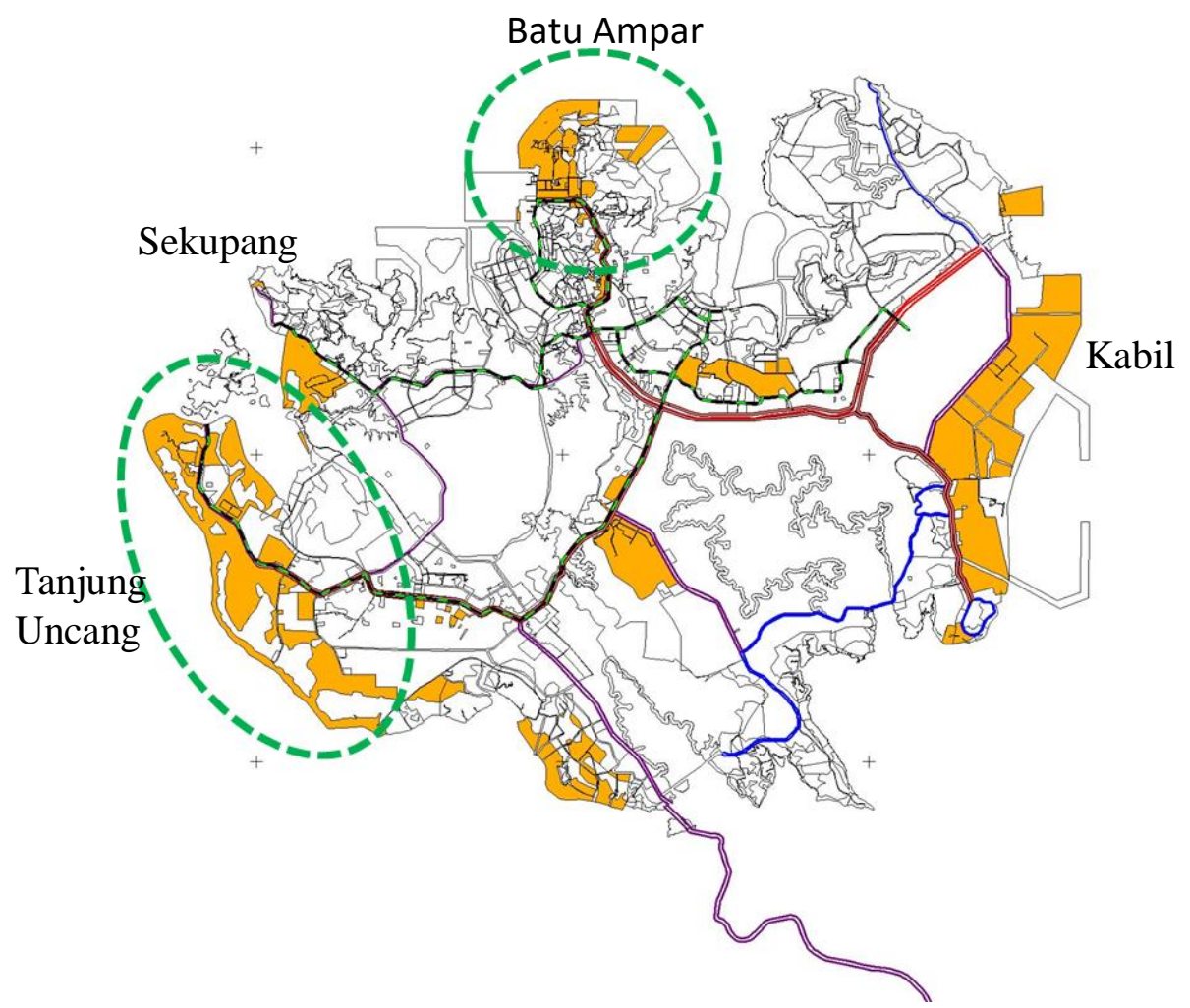

Gambar 2.

Persebaran Industri Perkapalan di Batam

Pada tabel 2 disajikan daftar nama keempat puluh enam industri perkapalan yang ada di wilayah KPBPB Batam.

Tabel 2. Daftar Industri Perkapalan di Wilayah KPBPB Batam 


\begin{tabular}{|c|c|c|c|}
\hline No & Nama Perusahaan & Jenis Industri & Lokasi \\
\hline 1 & Ably Metal Indonesia & Industri Pemotongan Kapal & Kabil \\
\hline 2 & Active Marine Industries & Barges, Tugboats, Perbaikan Kapal & Batam Kota \\
\hline 3 & Amnor Shipyard & Industri Kapal/Perahu dan industri Perbaikan Kapal & Sekupang \\
\hline 4 & Anggrek Hitam & Industri Pembuatan dan Perbaikan Kapal & Kabil \\
\hline 5 & ASL Shipyard Indonesia & Industri Perkapalan & Tanjung Uncang \\
\hline 6 & Bahtera Bahari Shipyard & Industri Perkapalan dan Perbaikan Kapal & Tanjung Uncang \\
\hline 7 & Bandar Abadi & Industri Perkapalan dan Perbaikan Kapal & Tanjung Uncang \\
\hline 8 & Bangun Karyasindo Utama & Pembuatan dan Perbaikan Tugboat dan Tongkang & bengkong \\
\hline 9 & Batam Expresindo Shipyard & Industri Kapal/Perahu dan industri Perbaikan Kapal & Tanjung Uncang \\
\hline 10 & Batamec & Galangan Kapal & Tanjung Uncang \\
\hline 11 & BH Marine \& Offshore Engineering & Pembuatan dan Perbaikan Perahu/Kapal & Sekupang \\
\hline 12 & Britoil Offshore Indonesia & Industri Pembuatan dan Perbaikan Kapal & Sekupang \\
\hline 13 & Bumi Laut Perkasa & Tongkang, Perbaikan Kapal & Tanjung Uncang \\
\hline 14 & Cahaya Samudra Shipyard & Jasa Perbaikan Kapal, New Building & Sekupang \\
\hline 15 & Canuarta Starmarine & Tugboat (pembuatan \& perbaikan); tongkang (pembuatan \& perbaikan) & Sagulung \\
\hline 16 & Citra Shipyard & Galangan Kapal & Tanjung Uncang \\
\hline 17 & Delta Shipyard & Industri Kapal/Perahu & Sagulung \\
\hline 18 & Dharma Sentosa Marindo & Jasa Pembuatan Kapal Laut & Tanjung Uncang \\
\hline 19 & Drydocks World Pertama & Industri Kapal dan Galangan Kapal & Tanjung Uncang \\
\hline 20 & Galangan Putra Tanjungpura & Industri Kapal/Perahu & Sagulung \\
\hline 21 & Graha Trisaka Industri & Industri Pembuatan Kapal \& Bangunan Lepas Pantai & Tanjung Uncang \\
\hline 22 & Jaya Asiatic Shipyard & Industri Pembuatan Tongkang dan Perbaikan Kapal & Tanjung Uncang \\
\hline 23 & Karya Tekhnik Utama & Industri Pembuatan Kapal dan Perahu & Sekupang \\
\hline 24 & Kim Seah Shipyard Indonesia & Industri Perkapalan & Sekupang \\
\hline 25 & Lautan Lestari Shipyard & Industri Pembuatan dan Perawatan Kapal Laut & Sagulung \\
\hline 26 & Lims Nautical Shipyard & Tugboat (pembuatan \& perbaikan); tongkang (pembuatan \& perbaikan) & Sagulung \\
\hline 27 & Marcopolo Shipyard & Tugboat (pembuatan \& perbaikan); tongkang (pembuatan \& perbaikan) & Sagulung \\
\hline 28 & Momentum Anugrah Indonesia & Tugboat (pembuatan \& perbaikan); tongkang (pembuatan \& perbaikan) & Batam Kota \\
\hline 29 & Nexus Engineering Indonesia & Industri Pembuatan dan Perbaikan Kapal & Kabil \\
\hline 30 & Pacific Atlantic Shipyard & Industri Pembuatan dan Perbaikan Tongkang & Sekupang \\
\hline 31 & Pacific Composite Utama & Industi Pembuatan Kapal/Perahu & Sekupang \\
\hline 32 & Palma Progress Shipyard & Industri Kapal dan Industri Perbaikan Kapal & Sagulung \\
\hline 33 & Pandan Bahari Shipyard & Industri Pembuatan Tongkang dan Perbaikan/ Perawatan Kapal & Tanjung Uncang \\
\hline 34 & Pioneer Offshore Indo Raya & Industri Kapal, Pemeliharaan/perbaikan kapal dan pabrikasi baja & Tanjung Uncang \\
\hline 35 & Sekupang Makmur Abadi & Perawatan dan Perbaikan Kapal, Penunjang Marine \& Offshore Supply Base & Sekupang \\
\hline 36 & Sentek Indonesia & Industri Perkapalan dan pemeliharaam/perbaikan kapal & Sei Lekop \\
\hline 37 & Sinbat Precast Teknindo & Industri Kapal, perbaikan kapal, jasa pemotongan kapal dan alat berat & Sekupang \\
\hline 38 & Sintai Industri Shipyard & Industri Pembuatan dan Perbaikan Kapal/Tongkang, Marine contractor, structure dan piping & Tanjung Uncang \\
\hline 39 & SKP Marine Engineering & Industri fabrikasi baja untuk perlengkapan dan peralatan kapal serta perbaikan mesin kapal & Tanjung Uncang \\
\hline 40 & Sumber Marine Shipyard & Industri Kapal dan Perahu, Jasa Reparasi Kapal, Perahu & Tanjung Uncang \\
\hline 41 & Sumber Samudra Makmur & Jasa Pembuatan dan Perbaikan Kapal Laut & Batu Merah \\
\hline 42 & Surya Prima Bahtera & Industri Kapal/Perahu /Industri Perbaikan Kapal & Nongsa \\
\hline 43 & Trikarya Alam & Industri Kapal/Perahu dan Perbaikan Kapal & Tanjung Uncang \\
\hline 44 & United Sindo Perkasa & Tugboat, barges, ship repairs & Kabil \\
\hline 45 & Venture Technology Indonesia & Industri Pembuatan dan Perbaikan Kapal & Sekupang \\
\hline 46 & World Wide Equipment South East & Perbaikan dan persewaan alat berat, ship repairs dan fabrikasi & Tanjung Uncang \\
\hline
\end{tabular}

Sumber : Direktorat Lalulintas Barang, 2012

Dari tabel di atas, dapat dilihat ada 18 industri ada di daerah Tanjung Uncang, 4 industri di daerah Kabil, 11 industri di daerah Sekupang dan 13 industri di daerah lainnya seperti Sagulung, Bengkong, Sei Lekop dan Batu Merah.

Jumlah industri perkapalan di Batam terus bertambah, dan sampai pada tahun 2014 sudah ada 113 industri, dan 54 industri diantaranya merupakan anggota BSOA (Batam Shipyard and Offshore Association).

Pengembangan industri perkapalan meliputi pembuatan dan perbaikan kapal diataranya membuat dan memperbaiki kapal, kapal tangki, kapal laut lainnya (termasuk konversi kapal untuk struktur lepas pantai/offshore), perbaikan kapal, pembuatan dan pebaikan mesin dan komponen kapal laut, pembuatan dan perbaikan armada pelesir, pemantik dan perahu. Selain itu juga jasa perawatan, perbaikan dan overhaul dan pabrik komponen mesin dan listrik. Jumlah pesanan kapal yang dibuat di Batam sendiri berasal dari luar negeri dan dalam negeri. Untuk pesanan dalam negeri, industri di Batam juga sudah bisa memproduki kapal TNI yang saat ini sedang dikerjakan sebanyak 30 Unit.

Secara garis besar, para pelaku (stakeholders) dalam klaster industri dapat dibagi ke dalam lima kelompok, yaitu : 
1. Industri Inti, yaitu industri yang merupakan fokus perhatian dan menjadi pengamatan kita dalam klaster, biasanya dijadikan titik maksud kajian.

Dalam kajian ini, adapun yang termasuk industri inti adalah industri perkapalan yang ada di wilayah Batam, yang saat ini sudah berjumlah 113 industri.

2. Industri Pemasok, yaitu industri yang memasok bahan baku, bahan pembantu atau kelengkapan lainnya, dengan kata lain industri yang menghasilkan produk-produk yang digunakan dalam proses produk industri ini yang dipasok antara lain : bahan baku utama, bahan tambahan dan aksesori.

Sedangkan untuk industri pemasok dalam kegiatan produksi di industri perkapalan meliputi Shipboard systems, Electrical systems, Automation systems, Paints \& Insulation, Furniture \& Deco, Navigation equipment, Mechanical equipment, Steel \& other materials dan yard maintenance

Beberapa contoh perusahaan yang termasuk dalam industri pemasok ini antara lain dapat dilihat dari Tabel 3.

Tabel 3.

Contoh Perusahaan Pemasok Industri Perkapalan

\begin{tabular}{|c|c|c|c|c|}
\hline No & Vendor & Location & Products or Services & Klasifikasi \\
\hline 1 & PT. Alussteel Engineering Indonesia & Batam & Subcon & Human Resources \\
\hline 2 & PT. ALYAA INDONESIA & Batam & Subcon & Human Resources \\
\hline 3 & PT. Aulia Arrahman & Batam & Subcon & Human Resources \\
\hline 4 & PT. BERGER BATAM & Batam & Subcon & Human Resources \\
\hline 5 & CV. Berkah Enginering & Batam & Subcon & Human Resources \\
\hline 6 & PT. Cool Dfine & Batam & Subcon & Human Resources \\
\hline 7 & PT. Evanindo Jaya & Batam & Supply \& Install Accomodation & Shipyard system \\
\hline 8 & PT. Evolet Indonesia & Batam & Subcon & Human Resources \\
\hline 9 & PT. Kembang Utama & Batam & Subcon & Human Resources \\
\hline 10 & PT. Musindo Ihsan Sejati & Batam & Subcon & Human Resources \\
\hline 11 & PT. Global Automation & Batam & Subcon & Human Resources \\
\hline 12 & PT. Natos Indonesia & Batam & Subcon & Human Resources \\
\hline 13 & Agility Shipping Pte Ltd & Batam & Shipping & Shipyard system \\
\hline 14 & Asuransi Bina Dana Arta, TBK & Jakarta & Asuransi & Shipyard system \\
\hline 15 & Batam Centre Hotel & Batam & Hotel & Shipyard system \\
\hline 16 & Batam Copier,CV & Batam & Rental Machine & Mechanical equipment \\
\hline 17 & Batam Logistic Pte Ltd & Batam & Shipping & Shipyard system \\
\hline 18 & $\begin{array}{l}\text { Batam Shipyard \& Offshore Association } \\
\text { (BSOA) }\end{array}$ & Batam & Association & Shipyard system \\
\hline 19 & Biro Klasifikasi Indonesia ( Persero ), P- & Batam & Class Certificated & Shipyard system \\
\hline 20 & $\begin{array}{l}\text { Bisnis Manajemen Solusi Indonesia, } \\
\text { PT }\end{array}$ & Jakarta & ISO & Shipyard system \\
\hline 21 & Buana Transperindo Wahana Internation & Batam & Shipping & Shipyard system \\
\hline
\end{tabular}

3. Industri Pendukung, yaitu industri yang mendukung suatu produk yang dihasilkan, dengan kata lain industri yang menyediakan jasa-jasa pendukung yang diperlukan untuk pelaksanaan program inti.

Dalam pelaksanaan klaster industri perkapalan nantinya, industri pendukung yang terlibat antara lain : 
Bank yang berperan dalam penyediaan dana kredit untuk industri perkapalan yang ada di Batam

Perusahaan penyedia air dan listrik

4. Pengguna, yaitu Industri yang memakai atau menggunakan produk yang dihasilkan industri inti. Pengguna atau pembeli dalam klaster industri perkapalan adalah konsumen yang berasal dari berbagai negara di dunia.

5. Institusi Pendukung, yaitu institusi non industri. Dalam klaster industri perkapalan di wilayah KPBPB Batam, adapun institusi pendukungnya meliputi :

a. BP Batam berperan sebagai lembaga pemerintah yang berfungsi sebagai fasilitator

b. BSOA (Batam Shiyard Off-Shore Association) sebagai asosiasi industri perkapalan

c. Insitusi pendidikan yang berperan dalam pelaksanaan melakukan penelitian yang berkaitan dengan klaster industry

d. Bea cukai, yang berperan dalam hal proses pengiriman dan penerimaan barang dari dalam dan luar negeri

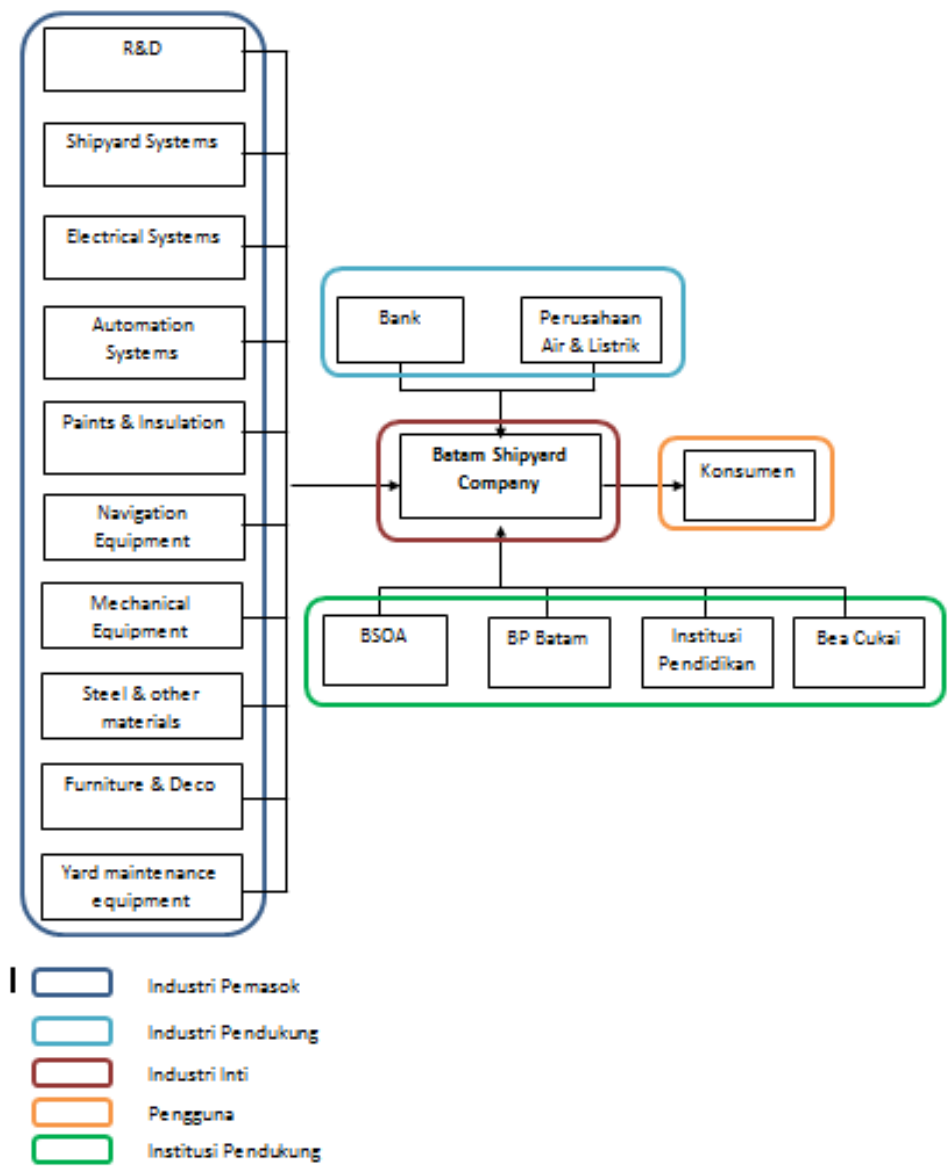

Gambar 3.

\section{KESIMPULAN}

Diagram Klaster Industri Perkapalan di Wilayah KPBPB Batam

Dari hasil penelitian, dapat disimpulkan bahwa :

Gambaran rantai nilai industri perkapalan di Batam adalah Rantai nilai yang berlaku di industri perkapalan di Batam bermula dari proses R\&D yang saat ini masih dilakukan oleh industri pemesan, dilanjutkan dengan kegiatan produksi pembuatan kapal dengan melibatkan industri pemasok yang ada di daerah Batam dan di sekitarnya serta dari luar negeri, seperti Singapura. Industri perkapalan di Batam, material yang digunakan sebesar $70 \%$ masih dipasok dari negera luar. Industri pemasok meliputi industri yang memproduksi Shipboard 
systems, Electrical systems, Automation systems, Paints \& Insulation, Furniture \& Deco, Navigation equipment, Mechanical equipment, Steel \& other materials dan yard maintenance. Selanjutnya dilakukan proses assembly dan penjualan kepada pemesan atau konsumen lainnya, yang diikuti juga dengan kegiatan service after sales, artinya memberikan layanan purna jual terhadap kapal yang sudah dibuat. Misalnya memberikan jaminan repair, maintenance dan konversi.

\section{DAFTAR PUSTAKA}

BP Batam. TT. Pengembangan Industri Perkapalan

BP Batam. 2013. Pemetaan Ketersediaan Ruang untuk 8 Klaster Industri Utama. BP Batam

Direktorat Lalulintas Barang, Biro Perencanaan Program dan Litbang BP Batam. 2012. Buku Data Investasi Orientasi Ekspor di Kawasan PBPB Batam. BP Batam

Frost \& Sullivan untuk BP Batam. 2011. Economic Master Development Plan (EMDP) for Batam, Bintan and Karimun (BBK) Region : Rencana Strategis \& Identifikasi Klaster Industri. BP Batam

Hadiguna, RA. 2014. Pembangunan Klaster Industri Alsintan Dalam Perspektif Supply Chain Management. Presentasi Jurusan Teknik Industri Universitas Andalas, PAdang

Hansen \& Clasen. 2010. The Economic Significance of Maritime Clusters, Lessons Learned from European Empirical Research. Danish Shipowner's Association

Hariyanto. 2013. Inisiatif Klaster Industri di Batam. Presentasi BPPT.

http://www.oecd.org/sti/ind/9\%20Reve\%20-\%20BI\%20-\%2029Nov2012.pdf

http://www.investindk.com/Clusters/Maritime-industry

Kementrian Perindustrian Republik Indonesia. TT. Roadmap Pengembangan Industri Perkapalan Nasional. Direktorat Maritim, Kedirgantaraan dan Alat Pertahanan Direktorat Jenderal Industri Unggulan Berbasis Teknologi Tinggi

Kurniawati \& Triwilaswandio. 2008. Rantai Pasok Material Pada Industri Galangan Kapal. Buletin PSP. Volume XVII. No. 3. Desember 2008

Warsono, A. 2012. Pola Klaster Industri Perkapalan untuk Mendorong Daya Saing Indsutri Perkapalan Nasional. Tesis Program Studi Teknik Perkapalan Universitas Indonesia, Jakarta

Widarsono, A. TT. Strategic Value Chain Analysis (Analisi Stratejik Rantai Nilai) : Suatu Pendekatan Manajemen Biaya. Program Studi Akuntansi Fakultas Pendidikan Ekonomi \& Bisnis, Universitas Pendidikan Indonesia (UPI BHMN) Bandung

Zhang \& Lam. TT. Analysis on Development Interplay between Port and Maritime Cluster 